\title{
REFLEXÕES SOBRE A LEI DE IMPROBIDADE ADMINISTRATIVA
}

José Carlos de Oliveira Alex Facciolo Pires

\section{RESUMO}

A Constituinte de 1988, buscando reprimir a corrupção, previu a figura da improbidade administrativa no art. 37 , parágrafo $4^{\circ}$. Foi editada, então, a Lei n. 8.429/92, Lei de Improbidade Administrativa. A má-fé, a desonestidade, a perversidade e a maldade, aliadas à ilegalidade, são premissas da improbidade administrativa. A Lei de Improbidade é aplicável a todos os agentes públicos, indistintamente, sem qualquer exceção, notadamente aos agentes políticos. Às ações por atos de improbidade administrativa não se aplica a prerrogativa de foro. A sanção consistente na perda da função pública produz o rompimento do laço entre o agente ímprobo e o Estado, porquanto o agente público exibiu inidoneidade moral e desvio ético para o exercício de qualquer função pública. Necessária alteração legislativa para mitigar a vedação à transação nos atos de improbidade administrativa. A eficácia da Lei de Improbidade Administrativa, apesar dos notáveis e expressivos avanços, ainda é diminuta frente aos desmandos de corrupção de que temos notícia pela imprensa, diariamente, proporcionando ainda, em realidade, uma verdadeira impunidade. 
Palavras-chave: Improbidade Administrativa. Agente Político. Prerrogativa de Foro. Perda da função Pública. Transação nos atos de improbidade administrativa. Proporcionalidade e Razoabilidade. Eficácia.

\section{INTRODUÇÃO}

O artigo 37 da Constituição Federal de 1988 tratou das disposições gerais sobre a Administração Pública, prevendo no parágrafo $4^{\circ}$ os atos de improbidade administrativa e suas sanções, buscando reprimir a corrupção. A Lei Federal n. 8.429/92, de 2-6-1992, foi o diploma legal que disciplinou e regulamentou a matéria. É na aludida lei que se tipificam os atos de improbidade administrativa e as espécies de cominações: sanção política, cível e administrativa.

A sanção política consiste na suspensão dos direitos políticos do agente ímprobo. A sanção político-administrativa consiste na perda da função pública e na proibição de contratar com o poder público e dele receber benefícios fiscais e creditícios. Por fim a sanção civil consistente na multa cível, ressarcimento integral do dano e perda dos bens ou valores acrescidos ilicitamente ao patrimônio.

Platão já salientava que a punição e o afastamento da vida pública dos agentes corruptos pretendem fixar uma regra proibitiva de que os servidores públicos não se deixem induzir por preço nenhum a agir em detrimento dos interesses do Estado $^{105}$.

Com efeito, conforme preconiza Walter Paulo Sabella, instalando-se como canal de evasão de recursos do erário, a corrupção atua como barreira impeditiva das atividades prestacionais do Estado, pois impossível admitir-se alguma espécie de serviço público cuja execução prescindisse de recursos públicos. A corrupção viola um direito fundamental à boa administração pública ${ }^{106}$.

Para que não se evite o perigo de uma administração corrupta caracterizada pelo descrédito e ineficiência, o legislador editou a Lei n.

\footnotetext{
105 PLATÃO. República. Bauru: Edipro, 1994, p. 197.

106 SABELLA, Walter Paulo. Ministério Público, combate à corrupção e controle das políticas públicas. Revista APMP - Associação Paulista do Ministério Público, São Paulo, n. 48, p. 29, 2008. <disponível em: http://justitia.com.br> acesso em 20 fev. 2011.
} 
8.429/92, com o intuito de prevenir a corrosão da máquina burocrática do Estado $^{107}$.

No dizer de Wallace Paiva Martins Júnior, a Lei n. 8.429/92 instituiu no direito brasileiro um autêntico código da moralidade administrativa ${ }^{108}$ e no ensinamento de Fábio Osório Medina, em seu livro Teoria da Improbidade Administrativa, prefaciado pelo Catedrático Emérito de Derecho Administrativo Eduardo García de Enterría, a Lei Federal n. 8.429/92 é, em verdade, uma Lei Geral de Improbidade Administrativa (LGIA) e, em realidade, um Código Geral de Conduta, com normativa jurídica, força coercitiva cogente, alcance nacional e balizador de todo o setor público, em suas vertentes fundamentais ${ }^{109}$.

E conforme preconiza Fábio Medina Osório:

São louváveis e necessários os avanços constatados na controlabilidade jurisdicional dos atos administrativos e ampliação das responsabilidades dos gestores públicos, no sistema jurídico brasileiro, diante da fragilização das imunidades do Poder. Eduardo García Enterría, nesse sentido, formulou clássico trabalho sobre $\mathrm{o}$ descabimento das imunidades do poder político, trabalho que veio a ser a base de uma série de transformações no direito administrativo espanhol, europeu e latino-americano, considerando um raio de influência direta daquele jurista. A luta contra as imunidades dos Poderes tem sido um dos temas centrais do constitucionalismo contemporâneo e da estruturação das instituições democráticas, onde se situam os sistemas administrativos e jurisdicionais que aplicam normas de direito administrativo ${ }^{110}$.

107 MORAES, Alexandre de. Direito constitucional. 26.ed. São Paulo: Atlas, 2011. p. 370.

108 MARTINS JÚNIOR, Wallace Paiva. Probidade administrativa. 4. ed. São Paulo: Saraiva. 2009, p. 199.

${ }^{109}$ OSÓRIO, Fábio Medina. Teoria da improbidade administrativa. São Paulo: Revista dos Tribunais. 2007, p. 21, p. 183.

${ }^{110}$ Idem. p. 21. 
Com efeito, a Lei de Improbidade Administrativa cataloga três grandes modelos de tipos sacionadores: a) condutas de enriquecimento ilícito (art. $\left.9^{\circ}\right)$; b) condutas de lesão ao erário (art. 10); e c) condutas de lesão aos princípios que regem a gestão pública (art. 11).

A lei n. 8.429/92 exigiu o dolo nas três espécies de atos de improbidade administrativa (arts. $9^{\circ}, 10$ e 11) e permitiu, em uma única espécie - art. 10 - também a responsabilidade a título de culpa.

Esse ensaio visa a evidenciar em letras fortes que a improbidade administrativa não é mera ilegalidade do servidor público, mas está qualificada pela má-fé, desonestidade, perversidade e maldade.

Ademais, a lei de improbidade administrativa, por ter conteúdo constitucional e sob pena de ferir o princípio constitucional da isonomia, deve ser aplicada, também, aos agentes políticos, porquanto o regime jurídico do impeachment previsto a eles não é incompatível com o regime jurídico constitucional da lei de improbidade administrativa, que prevê não somente a pena do cargo e a inabilitação do exercício de função pública por prazo determinado, mas também o ressarcimento do dano ao erário, perda dos bens ou valores auferidos ilicitamente, proibição de contratar com o poder público e dele receber benefícios fiscais ou creditícios e multa cível.

Destarte, a lei de improbidade administrativa não foi feita somente para os agentes públicos comuns. Não há qualquer exceção aos agentes políticos, consoante descrição clara e expressa no texto do artigo $2^{\circ}$ da Lei n. 8.429/92.

Analisamos a questão da prerrogativa de foro nas ações civis por improbidade administrativa. Será que o foro privilegiado de algumas autoridades na seara criminal se aplicaria nessas ações?

Noutro giro, refletimos também acerca da importância de uma alteração legislativa para mitigar a vedação de transação nos atos de improbidade administrativa. Com a possibilidade de composição ou acordo do legitimado com o agente ímprobo, penalidades rápidas seriam impostas ao agente corrupto, e a sociedade teria uma resposta imediata diante da prática da corrupção; a sensação de impunidade diminuiria, sem abrir mão, em qualquer hipótese, do ressarcimento integral do dano ao erário público causado.

Refletimos também acerca da necessidade de se entender que, na sanção consistente na perda da função pública prevista na Lei n. 8.429/92, exista o rompimento integral do laço entre o agente ímprobo e 
o Estado, porquanto o agente público, quando da prática do ato ímprobo, exibiu inidoneidade moral e desvio ético para o exercício de qualquer função pública, e não somente naquela exercida quando da prática do ato ímprobo.

E, finalmente, analisamos a eficácia do diploma legal em comento. Será que ele está sendo utilizado de maneira satisfatória e eficaz pelos legitimados à propositura de ações civis públicas por ato de improbidade administrativa? Reflitamos.

\section{O QUE É OU NÃO IMPROBIDADE ADMINISTRATIVA}

O vocábulo latino improbitate tem o significado de "desonestidade", e a expressão improbus administrator quer dizer "administrador desonesto ou de má-fé" 111 .

Na lição de Marcello Caetano, ao abordar o dever de probidade: "o funcionário deve servir à Administração com honestidade, procedendo no exercício de suas funções sempre no intuito de realizar os interesses públicos, sem aproveitar os poderes ou facilidades delas decorrentes em proveito pessoal ou de outrem a quem queira favorecer" ${ }^{\text {"112. }}$.

Segundo Fábio Medina Osório, o importante é situar a improbidade administrativa num marco ético-institucional, como espécie de má gestão pública:

A dificuldade reside em situar corretamente a improbidade no campo axiológico da má gestão pública, ou seja, como uma categoria éticonormativa apta a designar precisamente fenômenos situáveis no âmbito da má gestão pública. Realmente, a novidade consiste em posicionar a improbidade no universo rico e complexo da má gestão pública, deixando claro que se trata de conceitos próximos, porém distintos, na medida em

\footnotetext{
111 PAZZAGLINI FILHO, Marino. Lei de improbidade administrativa comentada. 4.ed. São Paulo: Atlas. 2009, p. 2.

112 CAETANO, Marcello. Manual de direito administrativo. Rio de Janeiro: Forense, 1970, p. 684.
} 
que nem toda má gestão pública será expressão da improbidade, ainda que o inverso seja verdadeiro ${ }^{113}$.

Conclui, referido autor, que a improbidade administrativa não é mero ato em desconformidade com letra fria da lei.

O fenômeno que designamos como improbidade administrativa, no direito administrativo brasileiro, desenhado no artigo 37, parágrafo $4^{\circ}$ da $\mathrm{CF}$, no marco da Lei n. 8.429/92, define-se como a má gestão pública gravemente desonesta ou gravemente ineficiente, por ações ou omissões, dolosas ou culposas, de agentes públicos no exercício de suas funções ou em razão delas, com ou sem participação dos particulares, observados os pressupostos gerais de configuração típica e de imputação. A improbidade é espécie do gênero má gestão pública. A corrupção é espécie do gênero improbidade. A compreensão desses fenômenos a partir dessas relações é fundamental para perceber suas características e peculariedades. A abordagem com o foco na ineficiência, quando sinalizada com nota de gravidade, também pode aproximar-se da própria corrupção, na medida em que ambas traduzem níveis distintos de má gestão pública e ambas constituem espécie de improbidade administativa. O próprio histórico da improbidade administrativa com elementos dos crimes de responsabilidade denuncia sua funcionalidade repressiva em relação a atos culposos. Daí por que resulta admissível, constitucionalmente, a improbidade culposa, dandose densidade ao princípio da eficiência ${ }^{114}$.

Neste aspecto, o Superior Tribunal de Justiça enfatizou:

\footnotetext{
113 OSÓRIO, Fábio Medina. Teoria da improbidade administrativa. São Paulo: Revista dos Tribunais. 2007, p. 29.

${ }^{114}$ Idem. p. 464.
} 
É cediço que a má-fé é premissa do ato ilegal e ímprobo. Consectariamente, a ilegalidade só adquire o status de improbidade quando a conduta antijurídica fere os princípios constitucionais da Administração Pública coadjuvados pela má-fé do administrador. A improbidade administrativa, mais que um ato ilegal, deve traduzir, necessariamente, a falta de boa-fé, a desonestidade, o que não restou comprovado nos autos pelas informações disponíveis no acórdão recorrido, calcadas, inclusive, nas conclusões da Comissão de Inquérito (Recurso Especial n. 480.387/SP - $1^{\text {a }}$ Turma - Rel. Min. Luiz Fux - DJU 16-3-2004) ${ }^{115}$.

Nesse mesmo sentido, vem decidindo o Tribunal de Justiça de São Paulo:

Improbidade é maldade, perversidade, corrupção, devassidão, desonestidade, falsidade, qualidade de quem atenta contra os princípios ou as regras da lei, da moral e dos bons costumes, com propósitos maldosos ou desonestos. Ausente essas características na inobservância formal do ordenamento, não há como aplicar pena por improbidade ao agente público (Apelação n. 400.147-5/5 - Auriflama, Rel. Des. Renato Nalini, DJ $15-8-2006)^{116}$.

Refletindo acerca do contexto apresentado, podemos revelar que foi com brilhantismo que lecionou Pazzaglini Filho ao asseverar que improbidade administrativa não é uma atuação do agente simplesmente em desconformidade com a letra fria da lei; não pode ser considerada como sinônimo de mera ilegalidade administrativa, mas deve ser conside-

\footnotetext{
115 BRASIL. Superior Tribunal de Justiça: jurisprudência. Disponível em: <http://www.stj.gov.br/portal_stj/ publicacão/engine.wsp>. Acesso em: 15 jan. 2012.

116 BRASIL. Tribunal de Justiça de São Paulo. jurisprudência. Disponível em: <http://www.tjsp.sp.br/portal_tj/ publicacão/engine.wsp>. Acesso em: 15 jan. 2012
} 
rada como uma ilegalidade qualificada pela imoralidade, desonestidade e má-fé ${ }^{117}$.

Valendo-se da lição de Marcelo Figueiredo, não nos parece crível punir o agente público, ou equiparado, "quando o ato acoimado de improbidade é, na verdade, fruto de inabilidade, de gestão imperfeita, ausente o elemento de desonestidade, ou de improbidade propriamente dita" 118 .

Nesse sentido:

Improbidade administrativa. Caracterização. Recurso provido. Segundo o Min. Luiz Fux, do STJ, a lei de improbidade administrativa, que explicitou o cânone do artigo 37 , parágrafo $4^{\circ}$, da $\mathrm{CF}$, teve como escopo impor sanções aos agentes públicos incursos em atos de improbidade nos casos em que: a) importem em enriquecimento ilícito (artigo $9^{\circ}$ ); b) que causam prejuízo ao erário público (artigo 10); c) que atentem contra os princípios da Administração Pública (artigo 11), aqui também compreendida a lesão à moralidade administrativa". Destarte, para que ocorra $\mathrm{o}$ ato de improbidade administrativa disciplinado pela referida norma, é mister o alcance de um dos bens jurídicos acima referidos e tutelados pela norma especial. O recebimento indevido de dupla remuneração para o exercício de uma mesma função, bem como seu irregular pagamento, evidencia má-fé objetiva dos apelados. É cediço que a má-fé é premissa do ato ilegal é ímprobo. Consectariamente, a ilegalidade só adquire o status de improbidade quando a conduta antijurídica fere os princípios constitucionais da Administração Pública coadjuvados pela má-fé do administrador. A improbidade administrativa, mais que um ato ilegal, deve traduzir, necessariamente, a falta de boa-fé, a desonestidade (Resp 480.387-SP, rel. Min. Luiz

117 PAZZAGLINI FILHO, Marino. Lei de improbidade administrativa comentada. 4.ed. São Paulo: Atlas. 2009, p. 03.

118 FIGUEIREDO, Marcelo. Probidade administrativa. 5. ed. São Paulo: Malheiros, 2004, p. $42 / 43$. 
Fux). <Disponível em: www.tj.mg.gov.br> Acesso em 15 jan. $2012^{119}$.

\section{APLICAÇÃO DA LEI DE IMPROBIDADE AOS AGENTES POLÍTICOS}

Valendo-se da lição de Celso Antônio Bandeira de Mello, a professora Maria Sylvia Zanella di Pietro entende que os agentes políticos são aqules que estão ligados indissociavelmente à noção de governo e à de função política. Por isso, apenas podem ser considerados agentes políticos os membros do alto escalão do Poder Executivo e do Poder Legislativo, que são o Presidente da República, os Governadores de Estado e do Distrito Federal, os Prefeitos e respectivos auxiliares imediatos (Ministros e Secretários de diversas pastas), os Senadores, Deputados Federais e Estaduais, do Distrito Federal e os Vereadores ${ }^{120}$.

A despeito, não há uniformidade de pensamento entre os doutrinadores na conceituação dos agentes políticos.

Para Hely Lopes Meirelles:

Os agentes políticos são os componentes do Governo nos seus primeiros escalaões, investidos em cargos, funções, mandatos ou comissões, por nomeações, designações ou delegação para o exercício de atribuições constitucionais. Ele inclui nessa categoria tanto os Chefes do Poder Executivo federal, estadual, distrital e municipal, e seus auxiliares diretos, os membros do Poder Legislativo, tais como Senadores, Deputados Federais, Estaduais e Distrital, Vereadores, como também os membros dos Tribunais de Contas, da Magistratura, do Ministério Público, representantes diplomáticos e demais autoridades que atuem com independência funcional no desempenho das atribuições

\footnotetext{
119 OSÓRIO, Fábio Medina. Teoria da improbidade administrativa. São Paulo: Revista dos Tribunais. 2007, p. 553.

${ }^{120}$ DI PIETRO, Maria Sylvia Zanella. Direito administrativo. 23. ed. São Paulo: Atlas, 2010, p. 512.
} 
governamentais, judiciais, estranhas ao quadro do funcionalismo estatutário ${ }^{121}$.

Mas o presente trabalho não pretende revelar a qual das posições doutrinárias assiste razão. Pretendemos refletir que a lei de improbidade administrativa se aplica aos agentes políticos.

Em 2007, o Plenário do Supremo Tribunal Federal proferiu decisão nos autos da Ação de Reclamação n. 2138-6 e por maioria absoluta (6 votos a 5) foi decidido que a Lei n. 8.429/92 (Lei de Improbidade Administrativa) não se aplicaria aos agentes políticos - Presidente da República, Ministros de Estado, Senadores, Deputados, Governadores, Prefeitos, Vereadores, Secretários, etc. porquanto a eles se aplicaria regime jurídico próprio previsto na Constituição Federal (juízo exclusivo - v.g. impeachement).

Marino Pazzaglini Filho, Márcio Fernando Elias Rosa e Waldo Fazzio Júnior afirmam que o Presidente da República, se autor de improbidade administrativa, não estaria sujeito às sanções de perda de função pública e suspensão dos direitos políticos, uma vez que estão sujeitos a regime jurídico constitucional próprio previsto nos arts. 85 e 86, ambos da Constituição Federal de 1988, ao disciplinar a cassação do Chefe do Executivo, e diante dos crimes de responsabilidade definidos pela Lei Federal n. 1.079/50 122 .

Ainda nesse sentido, a perda do mandato presidencial somente se verifica por crime de responsabilidade enunciado na Constituição da República e especificado em lei especial (Lei n. 1.079, de 10.4.1950). A competência para instaurar o processo é da Câmara dos Deputados e para processá-lo e julgá-lo é do Senado Federal, cabendo ao Presidente do Supremo Tribunal Federal presidir o julgamento. Eventual ação civil pública por ato de improbidade administrativa o Presidente da república responderia somente por sanções civis, descabendo as sanções de perda da função e de suspensão dos direitos políticos ${ }^{123}$.

121 MEIRELLES, Hely Lopes. Direito administrativo brasileiro. 29. ed. São Paulo: Malheiros, 2004, p. 75.

122 PAZZAGLINI FILHO, Marino; ROSA, Márcio Fernando Elias; FAZZIO JUNIOR, Waldo. Improbidade administrativa: aspectos jurídicos da defesa do patrimônio público. 4. ed. São Paulo: Atlas, 1999, p. 138.

123 PAZZAGLINI FILHO, Marino. Lei de improbidade administrativa comentada. 4.ed. São Paulo: Atlas. 2009, p. 139. 
Pazzaglini, acrescenta também que os senadores e deputados federais ou estaduais somente estariam imunes à perda do cargo, e não às demais sanções, pois o art. 15, V, da Constituição Federal prevê a mesma sanção para os casos de improbidade administrativa ${ }^{124}$.

A Lei n. 1.079, de 10-04-1950 definiu os crimes de responsabilidade do Presidente da República e demais autoridades federais e estaduais. Nesse diploma legal há crimes contra a lei orçamentária, previstos no art. 10 do Capítulo VI, há crimes contra a probidade da administração, e mais oito novos delitos, com o mesmo conteúdo típico daqueles aditados ao art. $1^{\circ}$ do Decreto-lei n. 201/67 (crimes de responsabilidade dos prefeitos).

Essas infrações penais, conforme preconizou Pazzaglini, são verdadeiros crimes de responsabilidade (próprios), pois sua punição é exclusivamente de conteúdo político-administrativo, consistente na perda do cargo e inabilitação, por oito anos, para o exercício de qualquer função pública, tanto que sua aplicação não exclui a responsabilidade penal de seu autor por crime comum previsto no Código Penal (arts. $2^{\circ}$ e $3^{\circ}$ da Lei n. $1.079 / 50)^{125}$.

Os crimes de prefeito estão previstos no art. $1^{\circ}$ do Decreto-lei n. 201, de 27-02-67 e vinculados ao exercício do mandato.

$\mathrm{O}$ art. $1^{\circ}$, parágrafo $2^{\circ}$, do diploma legal referido dispõe que a condenação definitiva em qualquer dos crimes definidos nesse artigo acarretará a perda do cargo e a inabilitação, pelo prazo de cinco anos, para o exercício de cargo ou função pública, eletivo ou de nomeação, sem prejuízo da reparação civil do dano causado ao patrimônio público ou particular.

A despeito do respeitado posicionamento susomencionado, em nenhum momento a Constituição reservou à instância do julgamento político-administrativo o caráter de jurisdição exclusiva dos agentes políticos, na medida em que repondiam e respondem pelo fato também civil e criminalmente.

Preconiza Wallace Paiva Martins Júnior que:

124 PAZZAGLINI FILHO, Marino. Lei de improbidade administrativa comentada. 4.ed. São Paulo: Atlas. 2009, p. 140.

${ }^{125}$ Idem. p. 156. 
É bem verdade que o art. 85 da Constituição Federal sujeita o Presidente da República à responsabilidade político-administrativa, inclusive por improbidade administrativa (inciso V), regulada na Lei $\mathrm{n}$. 1.079/50 aplicável a outros agentes políticos ali discriminados (Governandores de Estado, Ministros de Estado, Ministros do Supremo Tribunal Federal, Procurador Geral da República), com as sanções de perda do cargo e inabilitação para o exercício de qualquer função pública por prazo determinado, punições assemelhadas a algumas das previstas no art. 12 da Lei n. 8.429/92. A aplicação das penalidades da Lei n. 8.429/92 não é consumida pela aplicação das sanções político-administrativas, em razão da diversidade da natureza jurídica de cada uma delas e da própria extensão (prazos diferentes), sem que a extinção do mandato (renúncia, término, etc.) impeça a possibilidade da aplicação das demais sanções da Lei n. 8.429/92, sem a rejeição do processo político-administrativo ${ }^{126}$.

Ainda defende o referido autor que a responsabilidade políticoadministrativa somente tem como sanções a perda do cargo e a inabilitação temporária para o exercício de qualquer função pública, e as sanções decorrentes da Lei n. 8.429/92 abrangem a perda de bens ou valores ilicitamente acrescidos, o ressarcimento dos danos ao erário público, a proibição de contratar com o poder público ou dele receber benefícios ou incentivos fiscais ou creditícios e o pagamento da multa civil, além da perda da função pública e a suspensão temporária dos direitos políticos - art. 37, parágrafo $4^{\circ}$, da Constituição Federal e art. 12 da Lei n. 8.429/92 $2^{127}$.

E justifica sua assertiva refletindo que:

O que há são instâncias diferentes e autônomas para diversas qualificações jurídicas de um mesmo fato. Embora o efeito prática de algumas sanções seja equivalente, não há reserva ou exclusividade de "jurisdição" ao Poder Legislativo para repressão da improbidade administrativa. O regime republicano é o da responsabilidade sem comportar a

\footnotetext{
${ }^{126}$ MARTINS JÚNIOR, Wallace Paiva. Probidade administrativa. 4. ed. São Paulo: Saraiva. 2009, p. 311.

${ }^{127}$ Idem. p. 312.
} 
abertura de nichos de imunidade do poder, razão pela qual a Lei Federal n. 8.429/92 aplica-se a qualquer ato de improbidade administrativa de qualquer dos Poderes, abrangendo, pois, a improbidade em atos dos Poderes Executivo, Legislativo e Judiciário, sejam atos administrativos, legislativos ou jurisdicionais - art. $2^{\circ}$, Lei n. 8.429/92 $2^{128}$.

Também nesse sentido, Sílvio Antônio Marques:

Todo agente público que receber vantagem ilícita pode e deve ser investigado e processado nos âmbitos criminal, civil e administrativo. Excluir algumas autoridades apenas pelo fato de elas ocuparem cargos de alto escalão governamental infringe drasticamente o princípio da isonomia, previsto no art. $5^{\circ}$, caput, da própria Constituição Federal. Náo há qualquer fundamento razoável que exclua o Presidente da República e outras autoridades do espectro da Lei de Improbidade Administrativa $^{129}$.

Com razão, portanto, o Ministro Joaquim Barbosa, do Supremo Tribunal Federal, quando proferiu seu voto na Reclamação do STF n. 2.138:

(...) A meu sentir, a pretensa equiparação das condutas e sanções previstas na lei de improbidade a crimes de responsabilidade esvazia por completo o evidente caráter moralizador da Lei n. 8.429/92, restringindo seu alcance e aplicação. Afinal, a lei estabelece sanções aos agentes públicos nos casos de enriquecimento ilícito no exercício de mandato, cargo, emprego ou função na administração pública direta, indireta ou fundacional, sem prejuízo das sanções penais cabíveis. Em outros termos, o agente público passa a estar sujeito a outra espécie de sanção, de caráter não penal. E a averiguação das condutas contrária à lei de improbidade deve dar-se

\footnotetext{
${ }^{128}$ MARTINS JÚNIOR, Wallace Paiva. op. cit., p. 313.

129 MARQUES, Sílvio Antônio Marques. Improbidade administrativa. São Paulo: Saraiva. 2010, p. 61.
} 
no ambiente próprio do amplo processo jurisdicional em primeira instância, não havendo que se falar em prerrogativa de foro nesses casos" 130 .

Discordamos de Motauri Ciocchetti de Souza, porquanto ele assevera que o membro do Ministério Público somente pode perder o cargo em caso de procedência da ação civil pública específica, proposta pelo Procurador Geral, conforme previsto na Lei Orgânica Nacional do Ministério Público (Lei n. 8.625/93), que é posterior à Lei de Improbidade Administrativa. E os magistrados, segundo o mesmo autor, também não se sujeitam à referida sanção da lei de improbidade administrativa porque a Constituição Federal recepcionou a Lei Complementar n. 35/79 (Lei Orgânica da Magistratura Nacional), a qual, em seu art. 26, arrolou as hipóteses exaustivas de perda do cargo ${ }^{131}$.

Em que pese respeitável esse entendimento, não comungamos dessa tese, conquanto a Constituição Federal prescreve que o membro do Ministério Público e do Poder Judiciário obtém vitaliciedade após dois anos de exercício, não podendo perder o cargo senão por decisão judicial transitada em julgado. Não há, como se observa do referido texto constitucional, qualquer restrição à sentença proferida nos autos do processo da ação civil por ato de improbidade administrativa (arts. 95, I e 128, parágrafo $\left.5^{\circ}, \mathrm{I}, \mathrm{a}\right)^{132}$.

Conclui com acerto Sílvio Antônio Marques que: "Em suma, os agentes políticos, independentemente da posição hierárquica ou vínculo com o Poder Público, devem submeter-se às cominações por ato de improbidade administrativa"133.

Aliás, os agentes políticos representam 46,09\% dos réus que figuram no polo passivo das ações civis públicas por improbidade administrativa $^{134}$. E apenas $1,27 \%$ dos réus em ações civis públicas por ato de

\footnotetext{
${ }^{130}$ Idem. p. 62.

131 SOUZA, Motauri Ciochetti de. Interesses difusos em espécie: direito ambiental, direito do consumidor e probidade administrativa. São Paulo: Saraiva, 2000. p. 103

132 MARQUES, Sílvio Antônio Marques. Improbidade administrativa. São Paulo: Saraiva. 2010, p. 62.

133 Ibidem.

${ }^{134}$ Série Pensando o Direito, n. 34/2010. Improbidade administrativa. A eficácia do sistema jurídico de prevenção e combate à improbidade administrativa. Faculdade de Direito da Universidade de São Paulo - FDUSP. 2011, p. 53.
} 
improbidade administrativa são magistrados e $0,09 \%$ são promotores de justiça ${ }^{135}$.

Acaso o STF entenda que a lei de improbidade administrativa a eles não se aplica, somente os agentes públicos comuns é que sofrerão as penalidades previstas na lei n. 8.429/92.

Alguns agentes políticos somente sofrerão as sanções da perda do cargo e a inabilitação temporária para o exercício de qualquer função pública se houver autorização e aplicação das sanções pelo Poder Legislativo (art. 52 da CF). E se renunciarem ao cargo político ocupado serão impunes aos atos de corrupção praticados. Ainda assim estariam imunes do julgamento pelo Poder Judiciário.

\section{$3 \quad$ PRERROGATIVA DE FORO}

$\mathrm{Na}$ ação civil por improbidade administrativa não há competência originária para processar e julgar os réus que figuram no pólo passivo da demanda.

A despeito, durante governo do ex-Presidente da República Fernando Henrique Cardoso, por meio da Lei Federal n. 10.628/02 foi acrescentado dois parágrafos ao art. 84 do Código de Processo Penal, estendendo a prerrogativa de foro às ações civis de improbidade administrativa (parágrafo $2^{\circ}$ ), mesmo que o inquérito ou ação judicial sejam iniciados após a cessação do exercício da função pública (parágrafo $1^{\circ}$ ).

Portanto, tranferiu-se o julgamento para os Tribunais que, originariamente, julgavam as ações criminais.

$\mathrm{Na}$ ocasião, muitas vozes se levantaram a favor do foro privilegiado, justificando-se que um juiz de primeira instância não poderia suspender os direitos políticos ou declarar a perda do cargo do Presidente da República ou de um Ministro de um tribunal superior, por exemplo. E o Supremo Tribunal Federal já havia revogado a Súmula 394 que determi-

\footnotetext{
135 Série Pensando o Direito, n. 34/2010. Improbidade administrativa. A eficácia do sistema jurídico de prevenção e combate à improbidade administrativa. Faculdade de Direito da Universidade de São Paulo - FDUSP. 2011, p. 53.
} 
nava que a prerrogativa funcional perdurava após a cessação daquele exercício quando o crime fora cometido durante ele ${ }^{136}$.

A despeito, expressa é a Constituição Federal em seu art. 37, parágrafo $4^{\circ}$ que a ação de improbidade administrativa não tem natureza penal, mas civil, conforme magistério de Francisco de Almeida Prado ${ }^{137}$.

Também se argumentou nos Tribunais brasileiros que lei ordinária não poderia ampliar as hipóteses de competência originária decorrentes da Constituição Federal.

Por isso, tanto a Associação dos Magistrados Brasileiros (AMB) quanto a Associação Nacional dos Membros do Ministério Público (CONAMP) ajuizaram ADIns no Supremo Tribunal Federal, respectivamente ADIn 2797 e ADIn 2860, e referido Tribunal declarou, por maioria, a inconstitucionalidade dos parágafos $1^{\circ}$ e $2^{\circ}$ do art. 84 do CPP.

Em apertada síntese, decidiu-se que a ação de improbidade administrativa não tem natureza penal, mas civil. Que a competência originária dos Tribunais, é por definição, derrogação da competência ordinária dos juízos de primeiro grau, do que decorre que, demarcada a última pela Constituição, só ela a pode executar. A relatoria dos processos foi do Ministro Sepúlveda Pertence, em 15-5-2005.

Portanto, as ações por atos de improbidade administrativa devem ser ajuizadas em primeiro grau de jurisdição (juiz estadual ou federal, conforme o caso), não se aplicando a prerrogativa de foro prevista no texto constitucional.

\section{SANÇÃo DA PERDA DA FUNÇÃO PÚBLICA}

Uma das sanções cominadas aos agentes ímprobos consiste na perda da função pública. Esta sanção poderá ser imposta em qualquer das hipóteses delineadas nos arts. $9^{\circ}, 10$ e 11 da Lei n. 9.429/92. No entanto, será executada somente após o trânsito em julgado da decisão prolatada na ação civil pública.

\footnotetext{
136 MARQUES, Sílvio Antônio Marques. Improbidade administrativa. São Paulo: Saraiva. 2010, p. 205.

137 PRADO, Francisco Octávio de Almeida. Improbidade administrativa. São Paulo: Revistas dos Tribunais, 2001, p. 20.
} 
Mas o que se questiona é: a perda dessa função é aquela exercida quando da prática do ato ímprobo ou de qualquer outra função pública que o agente público exerça na época do trânsito em julgado da decisão judicial.

Exemplifiquemos: o contador de uma determinada Prefeitura Municipal comete ato de improbidade administrativa e é condenado. Mas, durante a ação civil pública, ele mesmo pede exoneração do cargo e depois é recontratado para exercer outro cargo (comissionado no Gabinete do Prefeito ou aprovado em concurso público para diferente cargo público municpal, estadual ou federal). Portanto, questiona-se: a sanção da perda da função pública, nesse caso, perdeu o objeto na ação civil pública porque o réu da ação já se desligou da função pública que exercia, ou, quando do trânsito em julgado da r. sentença ou V. Acórdão, o servidor é atingido pelos efeitos da sentença e deve perder também a nova função pública?

Preferimos a segunda assertiva.

Conforme preconiza com acerto Sílvio Antônio Marques:

A lei, em verdade, utilizou a expressão função pública em sentido amplo, significando o vínculo de qualquer pessoa física com órgão ou entidade pública, inclusive com as paraestatais. A sentença do magistrado ou tribunal competente, que nesse caso tem cunho constitutivo negativo, produz o rompimento do laço entre o agente ímprobo e o Estado. O coautor, partícipe, beneficiário ou herdeiro que não mantém vínculo com o órgão ou entidade pública obviamente não sofre essa penalidade, pois a lei á aplicável no que couber $\left(\operatorname{art} .3^{\circ}\right)^{138}$.

Também nesse sentido, Wallace Paiva Martins Júnior assevera que:

O agente público exibiu inidoneidade (ou inabilitação) moral e desvio ético para o exercício de função pública, expandindo-se para qualquer uma,

\footnotetext{
${ }^{138}$ MARQUES, Sílvio Antônio. Improbidade administrativa. São Paulo: Saraiva. 2010, p. 133.
} 
mesmo se em nível de governo diferente da executada quando praticado o ato ímprobo. De fato não há limitação: se o agente público era ímprobo quando exercia seu cargo efetivo na Administração Pública estatal, não foi a sentença que o constituiu na improbidade, mas a sua atuação, de forma que, se ao tempo do trânsito em julgado ele exerce cargo em comissão na Administração Pública federal ou outro cargo efetivo, a perda da função pública incidirá ${ }^{139}$.

A despeito, Carlos Alberto de Salles, no I Congresso do Patrimônio Público e Social realizado pelo Ministério Público do Estado de São Paulo, realizado entre os dias 18 e 21 de agosto de 2010, na cidade de São Paulo, tendo por tema jurídico a Efetividade da Lei de Improbidade Administrativa - 18 anos da Lei n. 8.429/92, entende que esta sanção somente atinge a função pública exercida na época do ato ímprobo, asseverando que o texto legal em apreço não empresta respaldo para conclusão em contrário, pois não seria simples perda, como indicado no texto legal, mas verdadeira vedação de exercício de função que o agente não possuía quando da prática da improbidade ${ }^{140}$.

Acaso esse entendimento prevaleça, além dos fundamentos já expostos, a impunidade continuará prevalecendo, pois basta o servidor ímprobo sair do cargo antes ocupado para se prover em outro. A nosso ver, outro incentivo à corrupção.

\section{TRANSAÇÃO NOS ATOS DE IMPROBIDADE ADMINISTRATIVA}

O artigo 17, parágrafo $1^{\circ}$ da Lei n. 8.429/92 veda expressamente acordo, transação ou conciliação nas ações civis públicas por ato de improbidade administrativa.

\footnotetext{
139 MARTINS JÚNIOR, Wallace Paiva. Probidade administrativa. 4. ed. São Paulo: Saraiva. 2009, p. 369.

${ }^{140}$ MINISTÉRIO PÚBLICO DO ESTADO DE SÃO PAULO. Centro de Apoio Operacional Cível e de Tutela Coletiva. Manual prático de atuação das promotorias de justiça de patrimônio público. São Paulo: Imprensa Oficial, 2011. p. 211
} 
Essa proibição legal tem por fundamento a indisponibilidade do direito tutelado e a aplicação das demais sanções civis, administrativas e políticas cominadas para os atos de improbidade praticados.

Marino Pazzaglini Filho vislumbra, como exceção à regra, uma única situação em que a transação, em caso de improbidade administrativa, poderia ser realizada, ou seja, quando o autor da ação (Ministério Público ou pessoa jurídica lesada) tão-somente postular, no caso de ato de improbidade administrativa que importa enriquecimento ilícito, a restituição integral do acréscimo patrimonial indevido e, na hipótese de ato de improbidade administrativa lesivo ao Erário, a reparação total da lesão patrimonial $^{141}$.

A questão é saber se seria cabível aos legitimados ativos da ação civil por ato de improbidade administrativa (Ministério Público ou pessoa jurídica interessada) transacionar com o ímprobo, com o intuito de aplicação imediata de alguma das sanções previstas no art. 12 da Lei n. 8.429/92, tornando-se a ação judicial desnecessária para tal finalidade.

Tem sido corriqueiro o Promotor de Justiça, no bojo de inquérito civil, fazer acordo com o agente público que causou prejuízo ao erário, garantindo o ressarcimento aos cofres públicos, de forma parcelada, sendo que, na sequência, arquiva o procedimento, sob o argumento de que não houve prova de improbidade administrativa, ou seja, de que o agente não agiu com dolo ou má-fé, o que justificaria o ajuizamento de ação civil pública por ato de improbidade administrativa.

Técnica e juridicamente um equívoco, porquanto se não existe improbidade administrativa, qual a razão pela qual instar o investigado a ressarcir o erário público?

Defendemos, fundamentados no advento da Lei $\mathrm{n}^{\circ} 12.120$, de 15-12-2009, que possibilitou a aplicação das sanções de forma isolada ou cumulativa de acordo com a gravidade do fato, e com alicerce nos princípios da razoabilidade e proporcionalidade, ser imprescindível a mitigação da vedação à transação na repressão aos atos de improbidade administrativa.

Objetiva-se, com isso, permitir a aplicação consensual de algumas sanções aos agentes ímprobos de forma imediata e rápida, sem batalhas judiciais de longa data.

141 PAZZAGLINI FILHO, Marino. Lei de improbidade administrativa comentada. 4.ed. São Paulo: Atlas. 2009, p. 205. 
No I Congresso do Patrimônio Público e Social realizado pelo Ministério Público do Estado de São Paulo, realizado entre os dias 18 e 21 de agosto de 2010, na cidade de São Paulo, tendo por tema jurídico a Efetividade da Lei de Improbidade Administrativa - 18 anos da Lei n. 8.429/92, a Coordenadora do Centro de Apoio Operacional das Promotorias de Justiça Cíveis e de Tutela Coletiva, Adriana Ribeiro Soares de Morais, preconizou:

Com efeito, o membro do Ministério Público realiza juízo de valor de razoabilidade e proporcionalidade de sanção, apenas de aplicação de multa civil e/ou proibição de contratar com o poder público ou receber benefícios fiscais ou creditícios, considerando, inclusive, o gasto econômico deste processo, o qual poderá arrastar-se por anos, com interposição de recursos extraordinários, inclusive $^{142}$.

Ainda Adriana Morais asseverou com bastante propriedade que, no âmbito cível:

Por que não aceitar a improbidade administrativa de menor potencial ofensivo? Neste caso, por que não permitir ao promotor de justiça a celebração de uma transação com o ímprobo, com o fim de, sem a propositura de ação civil, reconhecer o cometimento de ato de improbidade administrativa e concordar com o ressarcimento integral ao erário/perdimento dos bens ou valores, além de aplicação de uma ou mais sanções, dependendo da situação concreta a ser analisada pelo promotor de justiça, tendo como critério norteador as reiteradas decisões dos Tribunais Superiores, lastreadas nos princípios da razoabilidade e proporcionalidade das sanções? ${ }^{143}$.

\footnotetext{
${ }^{142}$ MINISTÉRIO PÚBLICO DO ESTADO DE SÃO PAULO. Centro de Apoio Operacional Cível e de Tutela Coletiva. Manual prático de atuação das promotorias de justiça de patrimônio público. São Paulo: Imprensa Oficial, 2011. p. 211.

${ }^{143}$ Ibidem.
} 
Não se desconhece que recente Acórdão do Superior Tribunal de Justiça, de relatoria do Ministro Herman Benjamin, afastou por completo a aplicação do princípio da insignificância, para o fim de reconhecer ato de improbidade administrativa na seguinte situação: "Chefe de Gabinete do Município que utilizou veículo de propriedade municipal e força de trabalho de três membros da Guarda Municipal para transportar utensílios e bens particulares". (Resp n. 892.818 - RS - Rel. Ministro Herman Benjamin, DJ: 10.02.10) ${ }^{144}$.

Destarte, exemplificamos nosso entendimento: o agente público adultera nota fiscal no processo de prestação de contas em regime de adiantamento, ou o agente público contrata funcionário fantasma para receber dois salários, ou mesmo, em outro caso, num processo licitatório não se respeita o prazo de publicidade previsto na lei de licitação (Lei n. 8.666/93). Em todos os exemplos, demandaria uma ação civil pública por improbidade administrativa que tramitaria por vários anos a fim de obter, após comprovado o dano ao erário e a má-fé e desonestidade do servidor ímprobo, o ressarcimento aos cofres públicos, proibição de contratar com o poder público, receber dele benefícios fiscais, perda do cargo e suspensão dos direitos políticos.

Nos casos supramencionados, poderia o promotor de justiça, adequando-se aos princípios da proporcionalidade e razoabilidade, transacionar com o agente ímprobo. Este reconhece sua má-fé e desonestidade, ressarce integralmente os cofres públicos e admite a aplicação de uma das demais sanções (perda do cargo, suspensão dos direitos políticos, multa civil ou proibição de contratar com o poder público), livrando-se das demais cominações.

Este ato de transação deve ser regulamentado em legislação própria, prevendo a transação e sob o crivo de homologação no Conselho Superior do Ministério Público. E mais, a alteração legislativa há de regular o valor em dinheiro permitido para se transacionar.

Por isso, é necessário que se encaminhe proposta de alteração legislativa à lei de improbidade administrativa, visando à mitigação da vedação à transação, acordo ou conciliação nas ações de improbidade administrativa.

${ }^{144}$ MINISTÉRIO PÚBLICO DO ESTADO DE SÃO PAULO. Centro de Apoio Operacional Cível e de Tutela Coletiva. Manual prático de atuação das promotorias de justiça de patrimônio público. São Paulo: Imprensa Oficial, 2011. p. 211. 
A resposta da atuação estatal à sociedade com a devolução ao erário público é imediata, aplicando-se ainda uma das demais sanções previstas. E evitar-se-iam longas batalhas judiciais sem os resultados desejados.

O Grupo Jurídico da ENCCLA (Estratégia Nacional de Combate à Corrupção e Lavagem de Dinheiro) do Ministério da Justiça firmou entendimento acerca da viabilidade de aplicação consensual de sanção no âmbito cível da improbidade, assegurando sempre o ressarcimento integral do dano e a aplicação de, pelo menos, uma das sanções previstas no art. 12 da Lei n. 8.429/92 ${ }^{145}$.

\section{$6 \quad$ EFICÁCIA DA LEI DE IMPROBIDADE ADMINISTRATIVA}

O Ministério Público vem exercendo, ao longo dessas duas últimas décadas, papel da maior relevância no contexto nacional, na defesa do patrimônio público e social. O relatório do Cadastro Nacional de Condenações Cíveis por Ato de Improbidade Administrativa, publicado em 17-1-2011, pelo Conselho Nacional de Justiça, revelou que foram cadastradas - pelos Tribunais de Justiça Estaduais e Tribunais Regionais Federais - 3.393 condenações dessa natureza, todas com trânsito em julgado. Desse total, 1.301, aproximadamente, 38\% oriundas do Tribunal de Justiça do Estado de São Paulo. Dados colhidos no SIS-MP Integrado do Ministério Público do Estado de São Paulo revelam que somente no ano de 2010, na área específica de defesa do Patrimônio Público e Social, foram instaurados 600 Procedimentos Preparatórios de Inquérito Civil e 4.327 Inquéritos Civis. Demonstram, ainda, que foram propostas 897 ação civis públicas por improbidade administrativa, com valores das causas totalizando mais de 2,5 bilhões de reais. No período de 1992 a 2009, o total de valores questionados para devolução ou ressarcimento aos cofres públicos do Estado de São Paulo e do Município de São Paulo, em ações civis públicas definitivamente julgadas procedentes e em fase de execução, supera os 138 milhões de reais. Se consideradas aquelas julgadas proce-

\footnotetext{
${ }^{145}$ MINISTÉRIO PÚBLICO DO ESTADO DE SÃO PAULO. Centro de Apoio Operacional Cível e de Tutela Coletiva. Manual prático de atuação das promotorias de justiça de patrimônio público. São Paulo: Imprensa Oficial, 2011. p. 212.
} 
dentes em $1^{\circ}$ grau, ainda pendentes de julgamento de recursos, o total ultrapassa 8 bilhões de reais, em valores nominais, não atualizados. ${ }^{146}$

No site no Ministério Público de São Paulo, diariamente, podem ser consultadas as ações contra agentes ímprobos (obtenção de liminar de indisponibilidade de bens de agentes públicos réus em ações por improbidade, suspensão dos direitos políticos, afastamento cautelar de agentes, condenações de prefeitos, vereadores, secretários, etc. por ato de improbidade administrativa).

A despeito, o volume de ações ainda é diminuto frente aos desmandos de corrupção de que temos notícias pela imprensa e, menor ainda nos Tribunais Superiores (STJ e STF), são as condenações que se perdem no tempo e na memória, proporcionando, em realidade, uma verdadeira impunidade.

Há discrepância exagerada entre uma região e outra do Estado no tocante ao número de ações por improbidade administrativa. Enquanto no Tribunal de Justiça de São Paulo e de Minas Gerais existem 8.152 e 3.436 ações civis públicas por improbidade administrativa, respectivamente, no Tribunal de Justiça do Pará e na Bahia há somente 63 e 75, respectivamente. De todo o acervo de ações civis públicas existentes nos Tribunais de Justiça do Brasil, 89\% são propostas pelos Ministérios Públicos estaduais e federal. As demais, pelas entidades lesadas (União, Estados, DF e Municípios). ${ }^{147}$

De todas as absolvições de ações civis públicas propostas pelo Ministério Público, $18,59 \%$ é por falta de provas quanto ao efetivo dano ao erário público.

A experiência processual revela que essa comprovação quanto ao efetivo dano ao erário púlbico é tormentosa, porquanto os próprios agentes públicos conluiados atestam falsamente recebimento de mercadoria e de materiais, bem como de execução de serviços públicos e medição de obras.

Por isso, é necessária a mudança legislativa com o fim de inversão do ônus da prova, porquanto, se o agente público pratica ato adminis-

\footnotetext{
146 MINISTÉRIO PÚBLICO DO ESTADO DE SÃO PAULO. Centro de Apoio Operacional Cível e de Tutela Coletiva. Manual prático de atuação das promotorias de justiça de patrimônio público. São Paulo: Imprensa Oficial, 2011. p. 212.

147 Série Pensando o Direito, n. 34/2010. Improbidade administrativa. A eficácia do sistema jurídico de prevenção e combate à improbidade administrativa. Faculdade de Direito da Universidade de São Paulo - FDUSP. p. 20, 2011.
} 
trativo com má-fé e desonestidade, visando ao fim proibido em lei e ofende os princípios da administração pública de forma dolosa e fraudulenta (art. 11 da Lei n. 8.429/92), deverá ele mesmo comprovar que não causou dano ao patrimônio público, ou seja, imprescindível a inversão do ônus da prova. ${ }^{148}$

Nesse sentido:

AÇÃO CIVIL PÚBLICA - Ausência de licitação Inteligência do Art. 24 da Lei no 8.666/93 - Indevido fracionamento de serviço contínuo - Ofensa aos princípios da moralidade, legalidade, impessoalidade e publicidade - Afastamento da condenação de devolução dos valores pagos, vez que o serviço foi efetivamente prestado e não há demonstração de superfaturamento - Recursos parcialmente providos. $<$ Disponível em https://esaj.tjsp.jus.br/cjsg/getArquivo.do?cdAcorda $\mathrm{o}=5682036>$ Acesso em 15 de fev. $2012^{149}$.

Um ponto positivo a ser realçado: de todas as ações civis públicas propostas pelos Ministérios Públicos (estaduais e federal), 63,82\% são julgadas procedentes ou parcialmente procedentes, revelando, ao contrário do que pensávamos, que as demandas do sistema judicial de combate à improbidade administrativa (corrupção) são acima do esperado. Esses dados permitem afastar a premissa de que a lei de improbidade administrativa é inefetiva, pelo menos no que tange à demanda de conhecimento condenatória ${ }^{150}$.

O problema é na fase executória, depois de anos e anos, o agente público já não mais está exercendo o cargo que exercia quando da prática da improbidade e dissipou todos os seus bens possíveis de ressarcir ao erário. Somente resta-nos a suspensão dos direitos políticos e a proibi-

\footnotetext{
148 Série Pensando o Direito, n. 34/2010. Improbidade administrativa. A eficácia do sistema jurídico de prevenção e combate à improbidade administrativa. Faculdade de Direito da Universidade de São Paulo - FDUSP. p. 20, 2011.

${ }^{149}$ SÃO PAULO (Estado). Tribunal de Justiça de São Paulo: jurisprudência. Disponível em: $<$ http://www.tjsp.jus.br/>. Acesso em: 15 fev. 2012.

150 Série Pensando o Direito, n. 34/2010. Improbidade administrativa. A eficácia do sistema jurídico de prevenção e combate à improbidade administrativa. Faculdade de Direito da Universidade de São Paulo - FDUSP. p. 20, 2011.
} 
ção de contratar com o poder público. Mais um motivo para sairmos em defesa da mitigação à proibição de transação, acordo ou composição nas ações civis por ato de improbidade administrativa.

\section{APONTAMENTOS CONCLUSIVOS E PROPOSTAS LEGISLATIVAS}

O regime jurídico constitucional da lei de improbidade administrativa é de suma importância, porquanto reprime a corrupção que fere de morte a democracia.

Com efeito, a Lei Federal n. 8.429/92 é, em verdade, uma Lei Geral de Improbidade Administrativa (LGIA) e, em realidade, um Código Geral de Conduta, com normativa jurídica, cogente e balizador de todo o setor público, em suas vertentes fundamentais.

Os atos de improbidade administrativa descritos no diploma legal supramencionado não devem ser banalizados de forma que apenas um descumprimento da letra fria da lei ou do descumprimento formal do ordenamento pode ser considerado ato ímprobo. A comprovação da maldade, má-fé, desonestidade e fraude são premissas essenciais para caracterizar o ato ímprobo, além da própria ilegalidade.

Os Tribunais Superiores (STJ e STF) devem seguir entendimento firme e uniforme no sentido de aplicar a lei de improbidade administrativa também aos agentes políticos, pois, a nosso ver, o diploma legal foi criado exatamente para eles, porquanto, invariavelmente, são eles os detentores do poder e que detêm competência para executar o gasto do dinheiro público. E como visto, são eles que mais aparecem no polo passivo das ações de improbidade administrativa que tramitam atualmente no Poder Judiciário brasileiro.

Já dizia Maquiavel que o povo tem objetivos mais honestos do que a nobreza; esta quer oprimir, enquanto o povo deseja apenas evitar a opressão ${ }^{151}$. É de suma importância controlar e punir com severidade aqueles que ocupam o alto escalão do Estado.

$\mathrm{O}$ Estado precisa dar à sociedade uma resposta mais rápida e uma punição mais imediata frente à prática diária dos atos de corrupção.

${ }^{151}$ PLATÃO. República. Bauru: Edipro, 1994, p. 57. 
E, para tanto, acreditamos que a mitigação à vedação à transação ou composição aos atos ímprobos deva acelerar a resposta estatal.

O agente, numa forma de transação com o Ministério Público ou órgão público lesado, reconhece sua má-fé, concorda em ressarcir integralmente o erário público e com a imposição de mais outra sanção prevista, e fica livre das demais sanções. Isso evita batalhas judiciais de longa data que está levando o Estado em descrédito, em razão da morosidade nos julgamentos dos agentes corruptos e ímprobos.

É lógico que a alteração da legislação disciplinará as hipóteses de transação e aplicação imediata das sanções, notadamente estipulando o limite do valor desviado ou fraudado, mas sempre mediante a devolução integral do dinheiro público.

Como apontado, portanto, algumas alterações legislativas da lei de improbidade são imprescindíveis para a maior efetividade do diploma legal em comento (inversão do ônus da prova quanto ao dano ao erário público, previsão expressa que a perda da função pública deve consistir no desligamento total do servidor ímprobo com a Administração Pública e mitigar a vedação ou proibição de transação e composição nos atos de improbidade administrativa).

O Brasil evoluiu muito no combate à corrupção, porquanto os números demonstram que nunca se processaram e condenaram tantos agentes públicos corruptos, políticos e particulares que, com eles praticaram atos de improbidade administrativa.

A despeito, o número ainda é diminuto frente ao crescente número de atos de corrupção que é veiculado na imprensa diariamente. Muito ainda há ser feito e realizado no combate à improbidade administrativa. Estamos num processo de transformação e amadurecimento.

\section{REFERÊNCIAS BIBLIOGRÁFICAS}

BRASIL. Superior Tribunal de Justiça: jurisprudência. Disponível em: <http://www.stj.gov.br/portal_stj/ publicacão/engine.wsp>. Acesso em: 15 jan. 2012.

CAETANO, Marcello. Manual de direito administrativo. Rio de Janeiro: Forense, 1970.

DI PIETRO, Maria Sylvia Zanella. Direito Administrativo. 23. ed. São Paulo: Atlas, 2010. 
ENTERRÍA, Eduardo García de. Curso de derecho administrativo II. 5.ed. Madri: Editorial Civitas, 1998.

FIGUEIREDO, Marcelo. Probidade administrativa. 5. ed. São Paulo: Malheiros, 2004.

MAQUIAVEL. O príncipe. 10. ed. São Paulo: MartinClaret, 2011.

MARQUES, Sílvio Antônio Marques. Improbidade administrativa. São Paulo: Saraiva. 2010.

MARTINS JÚNIOR, Wallace Paiva. Probidade administrativa. 4. ed. São Paulo: Saraiva. 2009.

MEIRELLES, Hely Lopes. Direito administrativo brasileiro. 29. ed. São Paulo: Malheiros, 2004.

MELLO, Celso Antônio Bandeira de. Curso de direito administrativo. 27.ed. São Paulo: Malheiros, 2010.

MINISTÉRIO PÚBLICO DO ESTADO DE SÃO PAULO. Centro de Apoio Operacional Cível e de Tutela Coletiva. Manual prático de atuação das promotorias de justiça de patrimônio público. São Paulo: Imprensa Oficial, 2011.

MORAES, Alexandre de. Direito constitucional. 26. ed. São Paulo: Atlas, 2011.

OSÓRIO, Fábio Medina. Teoria da improbidade administrativa. São Paulo: Revista dos Tribunais. 2007.

PAZZAGLINI FILHO, Marino. Lei de improbidade administrativa comentada. 4.ed. São Paulo: Atlas. 2009.

PAZZAGLINI FILHO, Marino; ROSA, Márcio Fernando Elias; FAZZIO JUNIOR, Waldo. Improbidade administrativa: aspectos jurídicos da defesa do patrimônio público. 4. ed. São Paulo: Atlas, 1999.

PLATÃO. República. Bauru: Edipro, 1994.

PRADO, Francisco Octáveio de Almeida. Improbidade administrativa. São Paulo: Revistas dos Tribunais, 2001.

SABELLA, Walter Paulo. Ministério Público, combate à corrupção e controle das políticas públicas. Revista APMP - Associação Paulista do Ministério Público, São Paulo, n. 48, p. 29, 2008.

SÃO PAULO (Estado). Tribunal de Justiça de São Paulo: jurisprudência. Disponível em: <http://www.tjsp.jus.br/>.

SÉRIE PENSANDO O DIREITO, n. 34/2010. Improbidade administrativa. A eficácia do sistema jurídico de prevenção e combate à improbidade administrativa. Faculdade de Direito da Universidade de São Paulo: FDUSP, 2011. 
SOUZA, Motauri Ciochetti de. Interesses difusos em espécie: direito ambiental, direito do consumidor e probidade administrativa. São Paulo: Saraiva, 2000. 